\title{
Legal Strengthening of Credit Agreement Based on Information Technology in Financial Technology Companies in Supporting Industry 4.0
}

DOI: https://doi.org/10.47175/rissj.v2i1.175

\section{| Ramlan |}

Faculty of Law, Universitas Muhammadiyah Sumatera Utara, Indonesia

ramlan_mosya71@yahoo.com

\begin{abstract}
Changes in the pattern of lending and borrowing also experienced growth over the development period. From a system that manually switches to digital. Since the existence of general information, technology-based credit services have been quite good in supporting industry 4.0, but there are still problems such as high-interest rates, and there are several debtor rights violated that need to be discussed regarding legal arrangements and legal strengthening. The research method is the type of normative legal research, how to collect data from library research and analysis of data with qualitative analysis. The results showed that financial technology regulation is regulated in the OJK Law, ITE Law, POJK, and $P B I$, and concerning legal reinforcement is needed for the problem of high-interest rates to debtors, electronic agreement standard clauses, threats, defamation, and violating customer privacy so that they can attract more many investors in supporting industry 4.0 with the use of financial technology, because the problem is only still regulated in the ITE Law has not been specifically applied in the implementation of financial technology.

KEYWORDS

credit; technology; interest; privacy; industry 4.0
\end{abstract}

\section{INTRODUCTION}

The times have brought about various changes in the system of life, one of which is the lending and borrowing process. This change occurred due to the demands of globalization and also the rapid growth of technology due to the industrial revolution which until now in the 4.0 era has become a major factor in the shift in the lending-borrowing process. The engagement process that was previously held face-to-face can now be carried out online with various limited companies that provide information technology-based financial services.

Article 57 paragraph (1) letter a of Law Number 21 of 2011 concerning the Financial Services Authority (OJK Law) states that "Since this Law is promulgated until the appointment of members of the Board of Commissioners as referred to in Article 56 paragraph (1), the Ministry of Finance assisted by Bank Indonesia to prepare: a. organizational structure, main tasks and functions, infrastructure design and information technology, human resource systems, and standard operating procedures";

The derivation of the OJK Law, financial technology has the legality to be empowered in Indonesia since the existence of the Financial Services Authority Regulation Number 77 of 2016 concerning Information Technology-Based Borrowing and Lending Services (POJK No.77 of 2016 concerning LPMUBTI) and Bank Indonesia Regulations Number 19/12/PBI/2017 of 2017 concerning the Implementation of Financial Technology. 
The presence of regulations regarding fintech is expected to encourage start-ups to support industry 4.0 and provide benefits to various sectors such as Business, Micro, Small and Medium Enterprises (MSMEs), increasing consumer spending interest, internet users and mobile banking.

Since then, many companies with legal entities in the form of limited liability companies have registered and processed their company licenses to join the fintech system. Based on data from Otoritas Jasa Keuangan (Financial Services Authority/OJK), as of November 2019, there were 164 companies in the form of registered or licensed Limited Liability Companies. Apart from unregistered ones, in 2017 there was 80 illegal fintech, in 2018 it increased to 108, in 2019 there were 399. There were 17,244,998 users of borrower accounts (borrowers) with an accumulated loan of Rp. 74.54 trillion. ${ }^{1}$

OJK emphasized that online loan interest from financial technology companies should not be greater than 0.8 percent per day. The loan interest regulation has no regulation. Although not regulated in the OJK regulations, Chairman of the OJK Board of Commissioners Wimboh Santoso said the imposition of a maximum interest rate of 0.8 percent per day was part of the code of ethics compiled by the Indonesian Joint Funding Fintech Association (AFPI). ${ }^{2}$

However, based on research by online lawyers, many applications provide an interest of $350 \%$ in 90 days, and it is also difficult to contact debt collectors, so consumers look for the addresses of related companies but the related companies do not provide an office address, email or telephone number that can be contacted. ${ }^{3}$

This weak regulation regarding information technology-based credit agreements is detrimental to customers because there are still illegal fintech companies and there are several companies that provide high-interest rates without the customer's knowledge. The determination of interest outside those stipulated by the OJK shows the lack of good investment management with an online credit agreement system that is not transparent. Of course, this will be detrimental to customers, plus the collection procedures that are unnatural and unsettling because it is different from the principles of banks that maintain customer privacy.

Based on the above problems, we will describe how the arrangement of information technology-based credit agreements in financial technology companies and legal strengthening of credit agreement based on information technology in financial technology companies in supporting industry 4.0.

\section{RESEARCH METHODS}

This type of research is normative legal research with a normative juridical approach. Normative juridical, namely finding the truth of coherence to examine whether there are legal rules according to legal norms and whether there are norms in the form of orders or prohibitions under legal principles, as well as whether a person's actions are by legal norms (not only according to legal rules) or legal principles. ${ }^{4}$

\footnotetext{
${ }^{1}$ OJK, "Data Financial Technology in Indonesia", www.ojk.go.id (accessed January 24, 2020).

${ }^{2}$ CNN Indonesia, "Bunga Pinjaman Online Terhadap Financial Technology di Indonesia", https://www.cnnindonesia.com/ekonomi/20190923140514-78-432990/ojk-tegaskan-bunga-pinjol-takboleh-lebih-dari-08-persen (diakses 24 Januari 2020).

${ }^{3}$ M. Agus Yozami, "Perkembangan Hukum Fintech di Indonesia", https://www.hukumonline.com/berita/baca/lt5c9b2221dcb1c/perkembangan-dan-ermasalahan-hukumfintech/ (accessed January 21, 2020).

${ }^{4}$ Peter Mahmud Marzuki, Penelitian Hukum (Jakarta: Prenada Media Group, 2014), p. 47.
} 
The method of data collection used in this research is through document study with library research. A literature study is a single method used in normative legal research. ${ }^{5}$ The data analysis method used is a qualitative analysis by describing it through words and sentences.

\section{RESULTS AND DISCUSSION}

\section{Arrangement Agreement of Credit Agreement based on Information Technology in Financial Technology Companies}

The 1945 Constitution adheres to the sovereignty of the Indonesian people which includes both aspects of political democracy and aspects of economic democracy. We can see the adoption of the principles of economic democracy and the understanding of the social market economy in the provisions of Chapter XIV of the 1945 Constitution. These constitutional provisions must underlie the formulation of various provisions concerning the economy and social welfare in Indonesia. The implementation of constitutional provisions in the economic sector will certainly always be in touch with the trend of community development. At present, the implementation of the welfare state understanding which provides a conceptual justification for the tendency of state market intervention should be limited for the development of a healthy business world. ${ }^{6}$

The business world is part of the market domain (market) concerning the state and civil society. So the business world must be developed together in a balanced manner with the domain of the state and civil society. For this reason, there must be a relationship between mutual influence and mutual control, so that there is no domination between one another. ${ }^{7}$

An economic system that is interconnecting and interoperating in a broad network (information networking) is also developing rapidly and is very complex and has not been regulated at all in the various existing regulations. Therefore, it is necessary to immediately develop various sets of regulations to ensure a uniform reference pattern which is increasingly being felt by the need. ${ }^{8}$

The principle of pacta sunt servanda is that judges or third parties may not intervene in contracts. Whoever has to respect the substance of the contract made by the parties, a contract made based on consensus is a rule that must be obeyed by the contracting parties. Article 1338 paragraph (1) BW states "contracts/agreements that are legally made are valid as law". Promises must be kept, keeping promises is human nature. This cooperation relationship will give birth to a contract containing rights and obligations. ${ }^{9}$ The results of the 2017 McKinsey Global Survey show that an increasing share of corporations use data and analysis as business models that generate financial growth. The financial growth of a company based on a data business model requires the right combination of strategy, culture and organization. The company monetizes data (monetizing data, capitalization data) as a means of financial growth. Although it is still in its early evolution, it seems that some of the fastest-growing (high performing) companies are already ahead of the rest. The digital

\footnotetext{
${ }^{5}$ Suratman, H. Philips Dillah, Metode Penelitian Hukum (Bandung: Alfabeta, 2015), p. 122.

${ }^{6}$ Jimly Asshiddiqie, Hukum Tata Negara dan Pilar-Pilar Demokrasi (Jakarta: Sinar Grafika, 2011), pp. 134135.

${ }^{7}$ Ibid., p. 135.

${ }^{8}$ Ibid., p. 188.

${ }^{9}$ Yahman, Karakteristik Wanprestasi dan Tindak Pidana Penipuan Yang Lahir dari Hubungan Kontraktual (Jakarta: Prenadamedia Group, 2015), p. 76.
} 
economy has the potential to increase the people's economy in Indonesia with 3 "sharing" pillars, namely economic sharing, trust sharing, and intelligence sharing. ${ }^{10}$

Convergence Law Theory is a conceptual and theoretical understanding of the convergence of technological, economic and legal variables on human and community relations in the 4.0 Industrial Revolution, both at the national, regional and international levels. The paradigm of convergence of the legal order can be carried out in a deeper understanding by examining the convergence and non-convergence conceptions of law. Approaches to finding a relationship with similarities or differences between legal systems, or comparing different legal systems, are expected to explain the importance of the convergence of laws. ${ }^{11}$

April 21, 2008 was a milestone for the development of law in Indonesia. On that date, the Government of Indonesia has enacted Law Number 11 of 2008 concerning Electronic Information and Transactions. The existence of this law proves that the Indonesian Government must follow the flow of globalization in all fields, including in electronic transactions which are different from legal actions in general. The enactment of this law also answers legal challenges in cyberspace or cyber law, which so far have not been specifically regulated in Indonesia. The characteristics of this cyber-legal act are, first, even though the legal action is carried out in a virtual world that does not recognize locus delicti, but it has real consequences (legal facts) so that the act must be considered a real act as well. Thus all the evidence that is available and uses information technology, such as e-mail and others, can be used as valid evidence. Second, this law also does not recognize regional boundaries (borderless) and who the perpetrators (legal subjects), so whomever the perpetrator is and wherever it exists is not so important as long as the act can have legal consequences in Indonesia. So, the most important thing here is that this legal action causes harm to the interests of Indonesia which includes but is not limited to detrimental to national economic interests, protection of strategic data, national dignity, defense and security, and Indonesian legal entities. ${ }^{12}$

Apart from the government which has the authority to make regulations related to various unregulated matters, the institutions that specifically have the authority to regulate fintech are Bank Indonesia and the Financial Services Authority. Several regulations related to fintech in Indonesia: 1. Bank Indonesia Regulation No.18/40/PBI/2016 concerning the Implementation of Payment Transaction Processing 2. Bank Indonesia Regulation No.19/12/PBI/2017 concerning the Implementation of Financial Technology 3. Regulation of Members of the Board of Governors No.19/14/PADG/2017 concerning Limited Trial Space (Regulatory Sandbox) of Financial Technology 4. Member Regulation of the Board of Governors No.19/15/PADG/2017 concerning Procedures for Registration, Submission of Information, and Monitoring of Financial Technology Operators. In line with the principle of freedom of contract, the debt agreement can be made in writing or not in writing (orally). Is it always necessary to make an acknowledgment of debt based on a written debt agreement? The answer is no. Because with the basic agreement orally, a debt acknowledgment can be made. The Civil Code acknowledges the existence of an oral agreement, provided there has been an agreement between the promised parties. The

\footnotetext{
${ }^{10}$ Danrivanto Budhijanto, "Hukum dan Revolusi Industri 4.0”, https://kumparan.com/danrivantobudhijanto/yurisdiksi-virtual-dalam-revolusi-industri-4-0-1553915193203304572 (accessed January 25, 2020).

${ }^{11}$ Ibid.

${ }^{12}$ Syafril Naldi, “Dasar Hukum Transaksi Elektronik”, https://uir.ac.id/opini_dosen/tantangan-hukum-di-erarevolusi-industri-4-0-oleh-syafrinaldi (accessed January 25, 2020).
} 
agreement is valid after being fulfilled as in the provisions of Article 1320 of the Civil Code. ${ }^{13}$

The development of times, the agreement of accounts payable is not about written or oral, but now without face to face, namely online. Especially regarding information technology-based credit agreements through companies that invest in financial technology systems, it is necessary to describe the agreement arrangements. Because, in this mechanism, start-ups that provide applications will bring together creditors and debtors through a cellular network.

Article 28C paragraph (1) of the Constitution of the Republic of Indonesia (UUD NRI) stipulates that "Everyone has the right to develop themselves through the fulfillment of their basic needs, has the right to receive education and benefit from science and technology, art and culture, to improve the quality of life. and for the welfare of mankind".

Article 3 of Law of the Republic of Indonesia Number 11 of 2008 concerning Information and Electronic Transactions (ITE Law) "Utilization of Information Technology and Electronic Transactions is carried out based on the principles of legal certainty, benefits, prudence, good faith, and freedom to choose technology or technology neutrality. Furthermore, in Article 17 paragraph (1) of the ITE Law, "Electronic Transactions can be carried out in the public or private sphere".

Article 5 paragraph (1) POJK No. 77 of 2016 concerning LPMUBTI "Providers provide, manage, and operate Information Technology-Based Lending and Borrowing Services from the Lender to the Borrower, whose source of funds comes from the Lender". For capital providers, accommodated in Article 16 paragraph (1) POJK No. 77 of 2016 concerning LPMUBTI "Lenders can come from within and/or abroad".

Article 18 paragraph (1) POJK No. 77 of 2016 concerning LPMUBTI contains that: The agreement for the implementation of Information Technology-Based Lending and Borrowing Services includes:

a. agreement between the Provider and the Lender; and

b. an agreement between the Lender

Article 19 paragraph (1) POJK No. 77 of 2016 concerning LPMUBTI: Agreement for the implementation of Information Technology-Based Borrowing and Lending Services between Providers and Lenders is outlined in an Electronic Document. The organizer's obligation to register is based on Article 48 POJK No. 77/2016 on LPMUBTI: The organizer must be registered as a member of the association appointed by the OJK.

Article 3 paragraph (1) Bank Indonesia Regulation Number 19/12 / PBI / 2017 of 2017 concerning the Implementation of Financial Technology (PBI Tekfin) stipulates that "Financial Technology Operations are categorized into:

a. payment system;

b. market support;

c. investment management and risk management;

d. loans, financing and provision of capital; and

e. other financial services.

Article 17 paragraph (1) of the PBI Tekfin stipulates that "Bank Indonesia shall supervise Financial Technology Operators in the form of Payment System Service Providers that have obtained a license and/or approval from Bank Indonesia".

The very rapid progress in the field of legal information as a result of automation can be seen from the figures, that in 1760 there were only 10 science magazines, now it is

${ }^{13}$ Gatot Supramono, Perjanjian Utang Piutang (Jakarta: Prenadamedia Group, 2014), p. 41. 
estimated that there are more than 250 million pages of information publications per year. One implementation of publication pages is used for e-commerce. ${ }^{14}$

How not the handling of civil cases and other cases that are examined by the court to arrive at a decision that has permanent legal force (in kracht van gewisde) takes years and costs a lot for justice seekers. ${ }^{15}$

According to Mariam Darus Badrulzaman, one of the principles of national engagement law is the principle of balance which is the principle that requires both parties to fulfill and implement the agreement. The creditor has the power to demand achievement and if necessary can demand the repayment of the achievement through the debtor's wealth, but the debtor also bears the obligation to carry out the agreement in good faith. ${ }^{16}$

In addition to the ITE Law, matters relating to defects in the formation of an agreement are regulated in the civil law book (burgerlijk wetboek). As for the kinds of defects of the will, namely: ${ }^{17}$

1. Mistakes (dwaling) Article $1322 \mathrm{BW} .{ }^{18}$

2. Coercion (dwang) article $1323 \mathrm{BW} .{ }^{19}$

3. Fraud (bedrog) article $1328 \mathrm{BW} .^{20}$

When legislation/regulation and government incentives are implemented, norms/rules are no longer adequate or they overlap. That is what is meant in the White Paper published by the World Economic Forum (WEF) in November 2016 that "Given the Fourth Industrial Revolution's extraordinarily fast technological and social change, relying only on government legislation and incentives to ensure the right outcomes is ill-advised. These are likely to be out-of-date or redundant by the time they are implemented ". 2018 in Argentina has ensured a mutual agreement in digital economic empowerment. G-20 Leaders' Declaration Building Consensus For Fair and Sustainable Development in point9 states that: ${ }^{21}$

"To maximize the benefits of digitalization and emerging technologies for innovative growth and productivity, we will promote measures to boost micro, small and medium enterprises, and entrepreneurs, bridge the digital gender divide and further digital inclusion, support consumer protection, and improve digital government, digital infrastructure and measurement of the digital economy. We reaffirm the importance of addressing issues of security in the use of ICTs. We support the free flow of information, ideas, and knowledge while respecting applicable legal frameworks, and working to build consumer trust, privacy, data protection, and intellectual property rights protection. We welcome the G20 Repository of Digital Policies to share and promote the adoption of innovative digital economy business models. We recognize the

\footnotetext{
${ }^{14}$ Andi Hamzah, Hukum Pidana Yang Berkaitan Dengan Komputer (Jakarta: Sinar Grafika, 1996), p. 116.

${ }^{15}$ Yahman, Op. Cit., p. 3.

${ }^{16}$ Ibid., p. 11.

${ }^{17}$ Ibid., p. 64.

${ }^{18}$ An error does not result in the cancellation of another agreement if the mistake occurs regarding the nature of the goods which are the subject of the agreement". R. Subekti, Kitab Undang-Undang Hukum Perdata (Jakarta: PT. Pradnya Paramita, 2004), p. 339.

19 "Coercion made against the person agreeing is a reason for the cancellation of the agreement, also if the coercion is carried out by a third party, for whose interest the agreement has not been made.", Ibid., p 340.

20 "Fraud is an excuse for canceling the agreement if the ruse used by one party is such that it is clear and obvious that the other party would not have made the contract if the deception was not carried out. Fraud is not suspected, but must be proven. ", Ibid.

${ }^{21}$ Republika Online, "Aturan-aturan Internasional tentang Revolusi Industri” www.republika.co.id/berita/pfckas423/relevansi-hukum-dan-teknologi-di-era-revolusi-industri40\%20diakses\%2018\%20Agustus\%202019 (accessed January 20, 2020).
} 
importance of the interface between trade and the digital economy. We will continue our work on artificial intelligence, emerging technologies and new business platforms."

The Asian region, especially ASEAN countries, has a major role in digital economic civilization as seen from the data from the International Monetary Fund (IMF) that "The digital economy has a massive and escalating character because of the ease and speed of access to information technology or internet media. With just one touch, data can be spread widely and change in various formats in a short time". The phenomenon of digital financial technology began with the emergence of data-focused business models, but only a few companies/corporations have achieved significant financial impact. ${ }^{22}$

The online credit agreement has been regulated in stages in positive law in Indonesia, but it needs to be further elaborated on the problems that arise and have not been regulated in the implementation of this financial technology so that legal strengthening is needed to support the current operation of Industry 4.0.

Referring to the theory of people's sovereignty, the highest power is in the hands of the people. The Constitution guarantees this as reflected in Article 1 paragraph (2) "Sovereignty is in the hands of the people and is exercised according to the Basic Law". The adoption of economic democracy by the Indonesian people must be implemented for the welfare of the people.

The relationship between the State and society in the business world cannot be separated. Some rights and obligations are mutually binding. The state must play an active role in overseeing the process of economic activities carried out by its citizens so that the State is not only limited to being a night watchman as has been termed in the libertarian political philosophy. The transition of the agreement from conventional to digital must hold on to legal certainty in carrying out economic activities so that there is a balance between business actors and consumers who are involved in the online lending and borrowing process.

It has not been comprehensively regulated regarding the legal implications that arise between the parties who enter into credit agreements through financial technology causing losses for parties who have not been given protection. An economic system with a very fast pace must also be accommodated by responsive laws. This includes anticipating the incomplete rules set in the online credit agreement process.

The regulations regarding online credit agreements are regulated in Article $28 \mathrm{C}$ of the 1945 Constitution of the Republic of Indonesia, Civil Code, Law Number 11 of 2008 concerning Electronic Information and Transactions, Bank Indonesia Regulation No.18/40/PBI/2016 concerning Implementation of Payment Transaction Processing, Bank Indonesia Regulations 19/12/PBI/2017 concerning the Implementation of Financial Technology, Regulation of Members of the Board of Governors No.19/14/PADG/2017 concerning the Regulatory Sandbox for Financial Technology, Regulation of Members of the Board of Governors No.19/15/PADG/2017 concerning Registration Procedures, Submission of Information, and Monitoring of Financial Technology Operators, POJK No. 77 of 20162016 concerning Information Technology-Based Lending and Borrowing Services.

Legal Strengthening of Credit Agreement Based on Information Technology in Financial Technology Companies In Supporting Industry 4.0

LBH Jakarta noted that until February 2019 it had received around 3 thousand public complaints regarding illegal fintech. Apart from LBH Jakarta, the Indonesian Joint

${ }^{22}$ Ibid. 
Funding Fintech Association (AFPI) received 426 complaints complaining about 510 P2P lending fintech platforms during the January-March 2019 period. Administrative costs. Then related to the high interest and administrative costs, the billing process in which there are criminal acts of slander, fraud, threats and dissemination of personal data up to sexual harassment. ${ }^{23}$

Prof. Benny Riyanto as Head of the National Law Development Agency in substance stated that "Civilizing the law by making Pancasila as a benchmark for national legal development to accommodate advances in information technology in industrial development 4.0 so that we will more easily adapt to the era of society $5.0 "{ }^{24}$

Law has a goal to be achieved, namely to create an orderly society, create order, balance and justice. Mochtar Kusumaatmadja said that by achieving order in society, it is hoped that human interests will be protected1. According to Satjipto Rahardjo, the presence of law is to integrate and coordinate interests that may conflict with one another. ${ }^{25}$

Legal development that leads to order also requires a legal strengthening in the process. For Marice Hauriou, the law is a process of strengthening, from the point of view of an individual human, the will to obey that rule is always weak. He will get stronger if there is support from others. The support of others is guaranteed thanks to the institutionalization of living together in existing institutions, including the state. It is this institution in the form of a state that ultimately determines the condition of people to obey the law. ${ }^{26}$

The existence of the Unitary State of the Republic of Indonesia is built from diversity. Long before Indonesia became independent and sovereign, togetherness above diversity had become the spirit and soul of the entire Indonesian nation. Departing from togetherness in diversity, the Indonesian state was born. Therefore, all implementation of the life of the nation and state must be based on togetherness and kinship. ${ }^{27}$

The principle of the Indonesian economic system, namely the principle of togetherness, is transformed into the nature of cooperation and a feeling of the same fate and acceptance in all aspects of life. Togetherness is realization, awareness, and determination to carry out and share the consequences of an action. The principle of togetherness built on diversity requires that each member receive and receive his portion according to the place and nature of his contribution. ${ }^{28}$

In the past, the process of borrowing prominently was carried out directly, manually, face-to-face, for example, a process carried out by lending and borrowing directly by the lender and the debtor who had to pay or previously borrowed and borrowed from the bank However, over time, financial technology companies emerged, including private economic actors with very large funds, which were able to provide unsecured loans with easy conditions to the public by bringing together borrowers and investors online without being face to face.

\footnotetext{
${ }^{23}$ M. Agus Yozami, "Perkembangan Hukum Fintech di Indonesia", https://www.hukumonline.com/berita/baca/lt5c9b2221dcb1c/perkembangan-dan-ermasalahan-hukumfintech/ (accessed January 21, 2020).

${ }^{24}$ BPHN, "Pembangunan Hukum dalam Mendukung Pembangunan Industri 4.0", https://bphn.go.id/news/2019101711365376/Pembangunan-Hukum-Dalam-Mendukung-Era-PembangunanIndustri-40-Dan-Society-50 (accessed January 22, 2020).

${ }^{25}$ Wahyu Nugroho. Rekonstruksi Teori Hukum Pembangunan Kedalam Pembentukan Perundang-Undangan Lingkungan Hidup Dan Sumber Daya Alam Pasca Reformasi Dalam Bangunan Negara Hukum. Jurnal Legislasi Indonesia. Vol. 14 No. 04 - December 2017 : 369 - 382.

${ }^{26}$ Bernard L. Tanya., dkk, Teori Hukum: Strategi Tertib Manusia Lintas Ruang dan Generasi, (Yogyakarta: Genta Publishing, 2013), p. 63.

${ }^{27}$ Munawir Ismail et al., Sistem Ekonomi Indonesia Tafsiran Pancasila \& UUD 1945, (Jakarta: Erlangga, 2015), p. 42.

${ }^{28}$ Ibid.
} 
This change is truly historical, both in terms of size, speed and scope. While deep uncertainty surrounds the development and application of new technologies, which means that we do not yet know how this industrial revolution-driven transformation will lead to its complexities and interconnections spanning a wide range of sectors which implies that all stakeholders of the global community (governance, companies, academia and civil society) have a responsibility to work together for a better understanding of these new trends. $^{29}$

Adam Gee said "You have to start from the point of view that no one cares" which is in line with Clayton Christensen's opinion. "Disruption replaces the old industrial market, and technology, and produces a novelty that is more efficient and comprehensive. It is destructive and creative! ". Disruption ultimately creates a new world: the digital marketplace. When the shape of the market changes, consumers will move too. Competitors now don't look like they used to. Politicians know very well that they are dealing with robots in cyberspace and invisible buzzers. ${ }^{30}$

Democracy does not guarantee the creation of a good bureaucracy, nor is it a prerequisite for successful bureaucratic reform. Once again, the key is political determination and the commitment of the national elite. Bureaucratic reform is not a program that is complete in one cabinet period, but a series of steps to reform that are consistent and sustainable between cabinets. ${ }^{31}$

The Central Bank is an institution that is very important in regulating and distributing money in the economic system. Regardless of the country, the stability of money remains the responsibility of the central bank. ${ }^{32}$ To be able to play a good role in allocating financial resources, the health and stability of banking institutions are crucial issues. Supervision and development of the banking industry are not only related to bank interests, more than that, the importance of this supervision also includes the good faith of banking institutions in responding to this monetary policy. Therefore, the state must have the ability to control and control the banking world. ${ }^{33}$

Adebayo et al (2017) conveyed the differences between banks and financial technology companies, namely:

"At present, the relationship between Internet finance and commercial banks should be a kind of competitive relationship, and the "carrier" of competition in the financial function possessed by both. Banks have been able to act as a financial intermediary, the most important reason is the information asymmetry. However, the rapid development of IT technology has greatly improved the sharing of customer data on the network and broke the traditional banking industry boundaries and regional structure". ${ }^{34}$

The link between finance organized via the Internet and commercial banks must compete competitively as both are engaged in finance. Banks and financial technology are both financial intermediaries that provide loans to borrowers. However, banks are still traditional while financial technology is digital so it is more practical and in line with the spirit of industry 4.0.

\footnotetext{
${ }^{29}$ Klaus Schwab, Revolusi Industri Keempat. Terjemahan oleh Farah Diena dan Andi Tarigan, (Jakarta: PT Gramedia Pustaka Utama, 2019), p. 12.

${ }^{30}$ Rhenald Kasali, Disruption, Tak ada yang Tak Bisa Diubah Sebelum Dihadapi, Motivasi Saja Tidak Cukup, (Jakarta: PT Gramedia Pustaka Utama, 2017), pp. 35-36.

${ }^{31}$ Boediono, Ekonomi Indonesia: dalam Lintasan Sejarah, (Bandung: PT Mizan Pustaka, 2016), p. 278.

${ }^{32}$ Munawir Ismail et al, Op. Cit., p. 139.

${ }^{33}$ Ibid., p. 143.

${ }^{34}$ Idowu Peter Adebayo, Balogun Jeremiah Ademola, Komolafe Olufemi, Egeruju Ngozi Chidozie. Information and Communication Technology Infusion Model for Microfinance Bank in Nigeria. International Journal of Finance and Banking Research. Vol. 3, No. 4, 2017, pp 57-69.
} 
The global financial crisis and barriers to obtaining bank loans have also disrupted Fintech (the use of innovative technology and business models in financial services) which, in its creative way, has provided an alternative way for SMEs to get funding for their growth. ${ }^{35}$

The Financial Services Authority (OJK) is pushing for the formation of a Law on Financial Technology (Fintech) to clarify the legal basis for the technology-based financial industry. Especially at this time, Indonesia does not yet have a strong legal basis to take action against illegal fintech players. This Fintech has no law, meaning that if it is made it will clarify its position in the law. From the explanation of what fintech is, then what business is it, who controls it, what is allowed and what is not. ${ }^{36}$

The problem behind the validity of electronic signatures in information technologybased credit which has been regulated in the ITE Law, POJK, is that in touch with the problem of standard clauses regulated in Law Number 8 of 1999 concerning Consumer Protection, it is often found in the field that many companies still apply clauses. standard in online credit agreements. Face-to-face, there are still many companies that do this, especially if the agreement is made without face to face, either in writing or orally, only online. Unilaterally, many companies still charge high-interest rates, the lack of OJK supervision makes the public fooled about this.

In general, the contents of the agreement with standard clauses benefit the creditor more than the debtor. The contents of the agreement tend to be unbalanced or one-sided, the creditor's rights are more than the obligations, while on the other hand, the debtor has more obligations than rights. ${ }^{37}$

Furthermore, many collectors from parties who gave loans made threats, defamed, and violated customer privacy by humiliating the borrower by announcing the loan to all contacts on the borrower's cellphone. This is because there is no mechanism for protecting customer privacy as implemented by banks.

Extortion and/or threats carried out through the internet media are regulated by Article 27 paragraph (4) which reads: "Everyone knowingly and without right distributes and/or transmits and/or makes accessible Electronic Information and/or Electronic Documents that have cargo extortion and/or threats". 38

Article 29 of the ITE Law stipulates "Every person knowingly and without right sends Electronic information and/or Electronic Documents that contain threats of violence or scare that are shown personally". 39

Defamation in electronic media is regulated in Article 45 paragraph (3) of Law no. 19 of 2016, which reads "Any person who knowingly and without right distributes and/or transmits and/or makes Electronic Information and/or Electronic Documents accessible which contain defamation and/or defamation as referred to in Article 27 paragraph ( 3) shall be sentenced to imprisonment for a maximum of 4 (four) years and/or a fine of not more than IDR 750,000,000.00 (seven hundred and fifty million rupiahs)".

Protection of personal data as a right to privacy is accommodated in: Article 26 Paragraph (1) of Law no. 19 of 2016, which states that "In the use of Information

\footnotetext{
${ }^{35}$ Wang Ping, Zhang Wenjian, Liu Jiao. Analysis of the Impact of Internet Finance on Banking Industry Development. International Journal of Finance and Banking Research. Vol. 3, No. 4, 2017, pp. 53-56.

${ }^{36}$ Sari, Ferrika, "Seputar Landasan Hukum Financial Technology di Indonesia", https://keuangan.kontan.co.id/news/perjelas-landasan-hukum-ojk-dorong-pembentukan-uu-fintech (accessed January 23, 20202020).

${ }^{37}$ Gatot Supramono, Op. Cit.,p. 22.

${ }^{38}$ Budi Suhariyanto, Tindak Pidana Teknologi Informasi (Cyber Crime) (Depok: PT Raja Grafindo Persada, 2014), p. 173.

${ }^{39}$ Ibid.
} 
Technology, protection of personal data is a part of personal rights (privacy rights). Personal rights contain the following meanings: a. Personal rights are the right to enjoy personal life and be free from all kinds of disturbances. b. Personal right is the right to be able to communicate with other people without being prudent. c. Personal right is the right to monitor access to information about a person's personal life and data".

The added complexity and rigor of financial regulation also raises an important consideration in continued support for the UK's new financial technology (FinTech), namely the challenge of balancing the need to stimulate but also regulate new emerging financial industries and emerging technologies. industries designed to support financial markets. Examples are blockchain and digital currency. Likewise, if current trends in financial regulation continue, non-bank entities will emerge to do things that large institutions cannot or do not choose. There is general agreement4 that UK financial regulations will benefit from implementing automated reporting and advanced analytics for compliance and risk measurement. ${ }^{40}$

HM Treasury is working on developing an open standard API for banks. In May 2015, the European Commission launched its Digital Single Market Strategy. Regulators must develop an understanding of consumer demand so that they can better appreciate which markets are developing. ${ }^{41}$

The solutions proposed are to strengthen governance and culture, improve data quality for risk data aggregation and risk reporting, combine cybersecurity and consumer data privacy, and manage the complexity of cross-border regulatory changes. ${ }^{42}$ There are 'new technology' capabilities that lead to digital convergence and disintermediation, new forms of money, and the expansion of financial services to previously unbanked consumers. ${ }^{43}$

Meanwhile, many of the unique practices for financial services are undergoing fundamental changes. They include growth towards mobile payments at scale and reduction in cash used in various regions of the world; changes in how international trade is financed based on new ways of achieving stakeholder information in supply chain management through IT; and the use of transaction filters to comply with political sanctions for movements of money in the global financial system. Also includes the growth of high-frequency and algorithmic trading; and cross-border equity trading, clearing and settlement, as global portfolio management is made possible by regional trading networks. There are also emerging technologies that create new opportunities for application: blockchain applications and ledgers between trading partners; new encoding capabilities for transaction tracing; and data mining and machine learning for pattern recognition and knowledge discovery. Cybersecurity and risks. Emerging capabilities for effective handling of financial, operational and compliance risks, fraud-aware electronic banking, and fraud assessment analytics, with particular emphasis on financial crime and money laundering, and intraday, and cross-border and intraday fund control innovations with IT . Institutions, institutional developments with technology, including clearinghouses, exchange and alternative trading systems, fund transfer networks, financial telecommunications, regulatory and government agencies, and central banks and governments. ${ }^{44}$

\footnotetext{
${ }^{40}$ Gulamhuseinwala, Imran., Bull, Thomas., Lewis, Steven., Whom Will Disrupt the Disruptors? The Journal of Financial Perspectives, (2015).

${ }^{41}$ Ibid.

${ }^{42}$ Amalia, Fitra, The Fintech Book: The Financial Technology Handbook For Investors, Entrepreneurs And Visionaries. Journal of Indonesian Economy and Business, Vol. 31, No. 3, (2016).

${ }^{43}$ Gomber, Peter., J. Kauffman, Robert ., W. Weber, Bruce., Financial Is, Underlying Technologies, And The Fintech Revolution, Journal of Management Information Systems, (2015). ${ }^{44}$ Ibid.
} 
Legal strengthening is urgently needed in the smooth running of information technology-based credit activities so that it does not harm debtors, especially concerning the problem of high interest, standard electronic agreement clauses, threats, defamation and violating customer privacy so that the rules in the ITE Law that are complete regulate this need to be applied in process of financial technology activities and also the need for increased supervision by $\mathrm{OJK}$ and $\mathrm{BI}$ as well as protection of customer data privacy in carrying out these lending and borrowing activities to promote start-ups and companies in the field of financial technology that utilizes technology so that through legal development of this technology can Indonesia be more ready again to compete in industry 4.0. Because in essence, financial technology is very supportive of the running of industry 4.0, especially if the existing problems can be overcome through legal development so that it can encourage Indonesia to be ready for the next eras.

\section{CONCLUSION}

Supporting industry 4.0 in Indonesia through strengthening the law on information technology-based credit agreements to advance start-ups and companies in the financial technology sector by not using standard clauses, containing detailed agreements such as interest information, and protecting the rights of debtors so that there is a data privacy protection and there is no defamation so that through legal development a healthy economic relationship can be created and can attract domestic and foreign investors to support financial technology. So, it is necessary to revise the relevant regulations so that the implementation of financial technology can run well.

\section{REFERENCES}

\section{Books}

Asshiddiqie, Jimly. (2011). Hukum Tata Negara dan Pilar-Pilar Demokrasi. Jakarta: Sinar Grafika..

Boediono. (2016). Ekonomi Indonesia: dalam Lintasan Sejarah. Bandung: PT Mizan Pustaka.

Hamzah, Andi. (1996). Hukum Pidana Yang Berkaitan Dengan Komputer. Jakarta: Sinar Grafika.

Ismail, Munawir., et al..(2015). Sistem Ekonomi Indonesia Tafsiran Pancasila \& UUD 1945. Jakarta: Erlangga.

Kasali, Rhenald. (2017). Disruption, Tak ada yang Tak Bisa Diubah Sebelum Dihadapi, Motivasi Saja Tidak Cukup. Jakarta: PT Gramedia Pustaka Utama..

Marzuki, Peter Mahmud. (2014). Penelitian Hukum. Jakarta: Prenada Media Group.

Schwab, Klaus. (2019). Revolusi Industri Keempat. Terjemahan oleh Farah Diena dan Andi Tarigan, Jakarta: PT Gramedia Pustaka Utama.

Subekti, R. (2004). Kitab Undang-Undang Hukum Perdata. Jakarta: PT. Pradnya Paramita. Suhariyanto, Budi. (2014). Tindak Pidana Teknologi Informasi (Cyber Crime). Depok: PT RajaGrafindo Persada.

Supramono, Gatot. (2014). Perjanjian Utang Piutang. Jakarta: Prenadamedia Group. Suratman., Dillah, H. Philips. (2015). Metode Penelitian Hukum. Bandung: Alfabeta.

Tanya, Bernard L., dkk. (2013). Teori Hukum: Strategi Tertib Manusia Lintas Ruang dan Generasi, Yogyakarta: Genta Publishing.

Yahman. (2015). Karakteristik Wanprestasi dan Tindak Pidana Penipuan Yang Lahir dari Hubungan Kontraktual. Jakarta: Prenadamedia Group. 


\section{Papers / Articles / Proceedings / Reports / Research Results}

Adebayo, IP., Ademola, BJ., Olufemi, Komolafe., Chidozie, EN, (2017). Information and Communication Technology Infusion Model for Microfinance Bank in Nigeria. International Journal of Finance and Banking Research. Vol. 3, No. 4.

Amalia, Fitra. (2016) The Fintech Book: The Financial Technology Handbook For Investors, Entrepreneurs And Visionaries. Journal of Indonesian Economy and Business, Vol. 31, No. 3.

Arrsa, Ria Casmi, (2013). Restorasi Politik Legislasi Pembentukan Peraturan Daerah Berbasis Riset (Restoration of Politics Legislation Establishment of Local Regulation Based Research), Jurnal Rechvinding, Vol. 2, No. 3, hlm. 397-415

Gomber, Peter., J. Kauffman, Robert ., W. Weber, Bruce., (2015). Financial Is, Underlying Technologies, And The Fintech Revolution, Journal of Management Information Systems.

Gulamhuseinwala, Imran., Bull, Thomas., Lewis, Steven. (2015). Whom Will Disrupt the Disruptors? The Journal of Financial Perspectives

Nugroho, Wahyu. (2017). Rekonstruksi Teori Hukum Pembangunan Kedalam Pembentukan Perundang-Undangan Lingkungan Hidup Dan Sumber Daya Alam Pasca Reformasi Dalam Bangunan Negara Hukum. Jurnal Legislasi Indonesia. Vol. 14 No. 04, hlm. $369-382$.

Ping, W., Wenjian Z., Jiao, L. (2017). Analysis of the Impact of Internet Finance on Banking Industry Development. International Journal of Finance and Banking Research. Vol. 3, No. 4.

Sari, Ferrika. (2020) "Seputar Landasan Hukum Financial Technology di Indonesia", https://keuangan.kontan.co.id/news/perjelas-landasan-hukum-ojk-dorong-pembentukanuu-fintech.

\section{Internet}

BPHN. (2020). "Pembangunan Hukum dalam Mendukung Pembangunan Industri 4.0", https://bphn.go.id/news/2019101711365376/Pembangunan-Hukum-Dalam-MendukungEra-Pembangunan-Industri-40-Dan-Society-50. Accessed January 22, 2020.

Budhijanto, Danrivanto. (2020). "Hukum dan Revolusi Industri 4.0", https://kumparan.com/danrivanto-budhijanto/yurisdiksi-virtual-dalam-revolusi-industri-40-1553915193203304572. Accessed January 25, 2020

CNN Indonesia. (2020). "Bunga Pinjaman Online Terhadap Financial Technology di Indonesia", https://www.cnnindonesia.com/ekonomi/20190923140514-78-432990/ojktegaskan-bunga-pinjol-tak-boleh-lebih-dari-08-persen. Accessed January 24, 2020.

Naldi, Syafril. (2020). "Dasar Hukum Transaksi Elektronik", https://uir.ac.id/opini_dosen/tantangan-hukum-di-era-revolusi-industri-4-0-olehsyafrinaldi. Accessed January 25, 2020.

Otoritas Jasa Keuangan, "Data Financial Technology di Indonesia", www.ojk.go.id Accessed January 24, 2020.

Republika Online (2020). "Aturan-aturan Internasional tentang Revolusi Industri" www.republika.co.id/berita/pfckas423/relevansi-hukum-dan-teknologi-di-era-revolusiindustri-40\%20diakses\%2018\%20Agustus\%202019. Accessed January 20, 2020.

Yozami, M. Agus. (2020). "Perkembangan Hukum Fintech di Indonesia", https://www.hukumonline.com/berita/baca/lt5c9b2221dcb1c/perkembangan-danermasalahan-hukum-fintech/. Accessed January 21, 2020. 


\section{Laws and regulations}

Law Number 21 of 2011 concerning the Financial Services Authority.

Law Number 11 of 2008 concerning Electronic Information and Transactions.

Law Number 19 of 2016 concerning Amendments to Law Number 11 of 2008 concerning Electronic Information and Transactions

Law Number 8 of 1999 concerning Consumer Protection.

Financial Services Authority Regulation Number 77 of 2016 concerning Information Technology-Based Lending and Borrowing Services

Bank Indonesia Regulation Number 19/12/PBI/2017 of 2017 concerning the Implementation of Financial Technology. 